\title{
Potential use of Piper nigrum ethanol extract against pyrethroid-resistant Aedes aegypti larvae
}

\author{
Utilização em potencial do extrato alcoólico de Piper nigrum \\ como larvicida em Aedes aegypti resistente a piretróides
}

\section{Naomi Kato Simas ${ }^{1}$, Elisangela da Costa Lima ${ }^{1,2}$, Ricardo Machado Kuster ${ }^{1}$, Celso Luiz Salgueiro Lage $^{2}$ and Alfredo Martins de Oliveira Filho ${ }^{1}$}

\begin{abstract}
Fractionation of Piper nigrum ethanol extract, biomonitored by assays on pyrethroid-resistant Aedes aegypti larvae yielded isolation of the larvicidal amides piperolein-A and piperine. Comparing $L C_{50}$ values, the ethanol extract $(0.98 p p m)$ was the most toxic, followed by piperolein$A$ (1.46ppm) and piperine (1.53ppm).
\end{abstract}

Key words: Piper nigrum. Aedes aegypti. Piperamides. Larvicide.

\section{RESUMO}

O fracionamento do extrato etanólico de Piper nigrum biomonitorado por ensaios em larvas de Aedes aegypti resistentes a piretróides resultou no isolamento das amidas larvicidas piperoleína-A e piperina. Comparando-se os valores de $C L_{5,}$ o extrato etanólico (0.98ppm) foi o mais tóxico, seguido pela piperoleina-A (1.46ppm) e piperina (1.53ppm).

Palavras-chaves: Piper nigrum. Aedes aegypti. Piperamidas. Larvicida.

Aedes aegypti is one of the mosquito species responsible for the transmission of both dengue fever and dengue hemorrhagic fever, which is endemic to South East Asia, the Pacific Islands area, Africa and the Americas ${ }^{11}$. Indeed, the present recrudescence of these diseases is partly due to the increasing resistance of mosquitoes to current commercial insecticides, particularly pyrethroids ${ }^{4}$. This problem has highlighted the need for the development of new strategies for selective mosquito larval control through a novel mode of action that does not confer cross-resistance to current insecticides.

The chemistry of Piper nigrum fruits has been extensively investigated and reveals a number of piperidine and pyrrolidine amides. The major constituent is piperine, which is responsible for the pungency of the fruit ${ }^{2}$. Recently, Park et $\mathrm{al}^{6}$ and Siddiqui et $\mathrm{al}^{789}$ performed studies on controlling Aedes aegypti larvae by isolating insecticidal constituents from Piper nigrum fruits. The same potential of Piper nigrum against Aedes aegypti was confirmed using ethanol extracts of plants cultivated in Brazil $^{10}$. The absence of reports regarding the potential use of Piper nigrum as a larvicidal agent against pyrethroid-resistant
Aedes aegypti strains gives rise to interest in investigating new insecticides that will not confer cross-resistance and are easily available at low cost. This paper describes a laboratory study aimed at isolating the insecticide constituent from Piper nigrum that is active against third-instar larvae of a pyrethroid-resistant Aedes aegypti strain.

\section{MATERIAL AND METHODS}

Plant material. Unripe Piper nigrum fruits were harvested from plants grown in the municipality of Monte Alegre, State of Pará, Brazil ( $\left.02^{0} 00^{\prime} \mathrm{S}, 5^{\circ} 06^{\mathrm{W}} \mathrm{W}\right)$, in the Amazon basin. Taxonomic identification of the plant was performed by Ricardo Secco, a botanist at the Emilio Goeldi Museum, Belém, Pará, where the voucher specimen was deposited (MG 156.772).

Plant extract. The dried fruits (1.4kg) of Piper nigrum were crushed and extracted exhaustively using ethanol at room temperature. The combined filtrate was concentrated in vacuum to yield $10 \%$ as a dark viscous extract. The crude

\footnotetext{
1. Centro de Ciências da Saúde, Núcleo de Pesquisas de Produtos Naturais, Universidade Federal do Rio de Janeiro, Rio de Janeiro, RJ. 2. Programa de Biotecnologia Vegetal, Universidade Federal do Rio de Janeiro, Rio de Janeiro, RJ.

Address to: Prof. Ricardo Machado Kuster. CCS/NPPN/Bloco H/UFRJ. Av. Brigadeiro Trompowski s/n, 21941-590, Rio de Janeiro, RJ.

Tel: $55212562-6792$

e-mail: kuster@nppn.ufrj.br

Recebido em: 15/02/2006

Aceito em 11/07/2007
} 
ethanol extract $(100 \mathrm{~g})$ was sequentially partitioned into hexane (20.5g), dichloromethane $(54.5 \mathrm{~g})$, ethyl acetate $(10 \mathrm{~g})$ and watersoluble (15g) portions for subsequent bioassay. Piperine was isolated by overnight precipitation of ethanol extract, resulting in $1 \%$ yield. The partitions and piperine were assayed against Aedes aegypti larvae. Bioassay-guided fractionation revealed that the dichloromethane partition was the most active one; hence, it was selected for further studies.

Fractionation of the dichloromethane partition. This was carried out by chromatography on XAD-16 resin using methanol and ethyl acetate as the eluting solvents. The active fraction PNPC17 $\left(\mathrm{LC}_{50}=\right.$ 2.3ppm) eluted with methanol was subjected to preparative thin layer chromatography using hexane/ethyl acetate (7:3) as the developing solvent to produce five bands (A to E). Biologically active band D $\left(\mathrm{LC}_{50}=1.04 \mathrm{ppm}\right)$ was further purified on silica gel with hexane/ethyl acetate (9.5:0.5) as the eluant, to yield the most active compound, which was PNPC17D-20A $\left(\mathrm{LC}_{50}=1.46 \mathrm{ppm}\right)$. The structure of this compound was determined as piperolein-A by spectroscopic analysis.

Bioassay test. The larvicide experiments were a slightly modified version of the standard protocol described by the World Health Organization ${ }^{12}$. The total volume in the test solutions was modified from the standard 250 to $20 \mathrm{ml}$. The volume modification was necessary to enable bioassaying of minor fractions resulting from the chromatography procedure. Bioassays were carried out using a cypermethrin-resistant colony of Aedes aegypti (NPPN colony) that was established from the adult survivors of a diagnostic dose of cypermethrin, (i.e. $\left.37 \mathrm{mg} \mathrm{ia} / \mathrm{m}^{2}\right)^{5}$. Ten thirdinstar mosquito larvae were placed in $19.9 \mathrm{ml}$ of distilled water and $100 \mu \mathrm{l}$ of ethanol solution containing the test fractions was added to each cup (50ml), which was shaken lightly to ensure a homogeneous test solution. The toxicity of each test fraction was determined with four to ten concentrations ranging from 0.1 to $1,000 \mathrm{ppm}$. The control was prepared with $19.9 \mathrm{ml}$ of distilled water and $100 \mu \mathrm{l}$ of ethanol to which larvae were added. The assay was conducted at room temperature in triplicates. Mortality was recorded 24 hours after treatment. The $\mathrm{LC}_{50}$ and $\mathrm{LC}_{99}$ values were calculated using the Probit analysis software (SPSS).

\section{RESULTS}

The susceptibility level of pyrethroid-resistant Aedes aegypti larvae for extracting fractions and piperine from Piper nigrum was determined. The ethanol extract was more active on third-instar Aedes aegypti larvae $\left(\mathrm{LC}_{50}=0.98 \mathrm{ppm}, \mathrm{LC}_{99}=2.72 \mathrm{ppm}\right)$ than was piperine $\left(\mathrm{LC}_{50}=1.53 \mathrm{ppm}, \mathrm{LC}_{99}=10.6 \mathrm{ppm}\right)$ or the hexane, dichloromethane, ethyl acetate or aqueous fractions. Bioassay-guided fractionation of the dichloromethane fraction produced an active crude fraction, and further chromatographic purification yielded piperolein-A $\left(\mathrm{LC}_{50}=1.46 \mathrm{ppm}, \mathrm{LC}_{99}=4.22 \mathrm{ppm}\right)$ as the major active compound.

\section{DISCUSSION}

The ethanol extract of Piper nigrum fruits exhibited potent larvicidal activity against the cypermethrin-resistant strain of
Aedes aegypti. The main larvicidal constituent of the extract was identified as the piperidine amide piperolein-A. Piperine, the main constituent of the fruit, presented an $\mathrm{LC}_{50}$ equivalent to piperolein-A activity.

The fractionation of Piper nigrum ethanol extract proved to be unnecessary for isolating the larvicidal compound, because the activity was gradually lost during the fractionation process. These findings are in agreement with Miyakado et $\mathrm{al}^{3}$, who reported the use of piperamide mixtures to increase the larvicidal activity in a pyrethroid-resistant Culex quinquefasciatus mosquito strain. Furthermore, piperine has been reported to enhance the bioavailability of several drugs, possibly by inhibiting drug metabolizing enzymes and/or increasing their absorption ${ }^{1}$. Possibly, the toxicity of Piper nigrum ethanol extract towards pyrethroid-resistant strains of Aedes aegypti is increased by its piperine content. The use of crude Piper nigrum ethanol extract as the larvicide decreased its cost by avoiding the purification processes. This is the first report of Piper nigrum larvicidal activity on a pyrethroid-resistant strain of Aedes aegypti.

In conclusion, the larvicide property of crude Piper nigrum ethanol extract indicates that its compounds did not confer cross-resistance to pyrethroid-resistant strains. The extract could be useful for managing field populations of pyrethroidresistant Aedes aegypti larvae when the other control methods are not promptly accessible. The pronounced taste of the extracts will probably be a problem regarding their use in drinking water. However, it could be overcome by appropriate formulations or its use in non-drinking waters. Further studies on their effects on non-target organisms and the environment, and regarding formulations to improve the insecticide potency and stability, are needed for these naturally occurring mosquito larval control agents to be used in practice.

\section{REFERENCES}

1. Bajad S, Bedi KL, Singla AK, Johri RK. Piperine inhibits gastric emptying and gastrointestinal transit in rats and mice. Planta Medica 67: 176-179, 2001.

2. Epstein WW. Isolation of piperine from black pepper. Journal of Chemical Education 70: 598-599, 1993.

3. Miyakado M, Nakayama I, Ohno N, Yoshioka H. Structure, chemistry and actions of the Piperaceae amides: New insecticidal constituents isolated from the pepper plant. In: Whitehead DL, Bowers WS (eds) Natural products for innovative pest management; Pergamon Press, New York, Volume 2, p.369-382. 1983.

4. Oliveira Filho AM. A resistência dos insetos aos inseticidas, a situação atual do Aedes aegypti e a explosão do dengue no Rio de Janeiro em 2002. Vetores \& Pragas 11: 9-13, 2002

5. Oliveira Filho AM, Netto BM, Loureiro FF, Melo MTV, Santos CE, Costa EG, Damião OC, Souza JJ. Determinação da linha básica de suscetibilidade e da dose diagnóstica da cipermetrina em Aedes aegypti. Revista da Sociedade Brasileira de Medicina Tropical 34 (supl I): 54, 2001

6. Park IK, Lee SG, Shin SC, Park JD, Ahn YJ. Larvicidal activity of isobutylamides identified in Piper nigrum fruits against three mosquito species. Journal of Agricultural and Food Chemistry 50: 1866-1870, 2002.

7. Siddiqui BS, Gulzar T, Begum S. Amides from the seeds of Piper nigrum Linn. and their insecticidal activity. Heterocycles 57: 1653-1658, 2002.

8. Siddiqui BS, Gulzar T, Begum S, Afshan F, Sattar FA. Two new insecticidal amide dimmers from fruits of Piper nigrum Linn. Helvetica Chimica Acta 87: 660-666, 2004 . 
9. Siddiqui BS, Gulzar T, Begum S, Rasheed M, Saftar FA, Afshan F. Two new insecticidal amides and a new alcoholic amide from Piper nigrum Linn. Helvetica Chimica Acta 86: 2760-2767, 2003.

10. Simas NK. Análise química, biológica e biotecnológica de espécies vegetais com atividade larvicida em Aedes aegypti. Tese de doutorado, Universidade Federal do Rio de Janeiro, Rio de Janeiro, RJ, 2003.
11. Vasilakis N, Shell EJ, Fokam EB, Mason PW, Hanley KA, Estes DM, Weaver SC, Potential of ancestral sylvatic dengue-2 viruses to re-emerge. Virology 358: 402$412,2007$.

12. World Health Organization. Insecticide resistance and vector control. Technical Report Series, $n^{\circ} 443,1970$. 